\title{
From Mythological Ages to Contemporary Ages: Child Education
}

\author{
Halide Gamze İnce Yakar \\ Correspondence: Halide Gamze İnce Yakar, Turkish Language Department, Okan University, Tuzla Campus, İstanbul, \\ Türkiye.
}

Received: January 11, 2018

doi:10.11114/jets.v6i2.2962

\author{
Accepted: January 28, 2017 \\ Online Published: January 29, 2018 \\ URL: https://doi.org/10.11114/jets.v6i2.2962
}

\begin{abstract}
Seeking the solution to the problems of contemporary man and approaching the social events through mythology is the other way to use the healing power of literature education. Having served as a guide for people in the past, mythology is the mirror of the past, which indicates the reasons and possible results of the events that have experienced today. The communities, which internalize the information well through myths, can direct their future, as well. In this study, we aim to examine the child education and the social problems that arise as a result of this education through the protagonist of Duca Kocaoğlu Deli Dumrul story, his relation with his parents and his life told in one of the twelve texts in the Book of Dede Korkut, which is an epic of Oghuz Turks. To this end, Suphi Altındöken, which had sparked a debate by killing Özgecen Aslan, a university student in Mersin in 2015, and Deli Dumrul, who shows relatively different characteristics from the other protagonists in the Book of Dede Korkut will be compared by their education that they receive from their parents and the environment that they grew up. In this comparison, we have used two tragedia; of Alcestis and of Antigone by Euripides and Sophocles, two playwrights from 5th and 4th centuries B.C. respectively, and used the story of Dumrul and Azrael, published by Murathan Mungan in 2000. In the context of a mythological story from the 12th century and an event from the 21st century, the main elements of child education, especially the parents' attitude, will be included.
\end{abstract}

Keywords: mythology, child education, deli dumrul, suphi altındöken, literature education

\section{Introduction}

Throughout the history of mankind, societies have produced myths about unusual developments that they have experienced. It is possible to find a social problem today or the traces of similar things in history or in mythology. Joseph Campbell, in his book titled Power of Mythology, said that it might be possible to find a mythological precedent for a problem if one can find where s/he is blocked (Campbell, 2013, p.186). In this way, it may be suggested to examine the solutions produced by mythology by finding and analyzing similarities in mythology for problems that societies can not solve. Mythology explains the causes of events, not the events (Bayat, 2007, p.12). Myths are a guide to many issues. Mythological texts, in a poem or a short story, colorize their amazing and common lessons in many different ways (Dumezil, 2012, p.631-632).

In mythological stories, it is possible to find the values, relations and transfers of the mythological period societies to the next generations, in the deep meaning layers of the messages. Myths teach us how to behave (Armstrong, 2014, p.9).

In our study, a murder experienced in Turkey in 2015, which was discussed long-term and remained in the agenda, will be traced in the Turkish mythology and in terms of child education, the results of two events, one real and one mythological event, will be examined. We will discuss the changed values in the Turkish society, transferred values and the messages derived from the solutions created for these problems since Dede Korkut Epic up to present, under the title of child education.

\subsection{2th Century - The Epic of Dede Korkut}

Epic of Dede Korkut, whose original name is "Kitab-i Dede Korkut ala Lisan-i Taife-i Oğuzan" which is one of the most important products of the oral tradition of Turkish folk literature, is the story of the Oghuz Turks in the east of Anatolia XII. and XIII century, the way of them seeing the world, their fascination, traditional lifestyle and the family structure. It is thought to have been written in the 15th century, although not certain, yet. There are 12 stories about different events in the epic apart from the introduction. The stories in the epic are told in the mouth of Dede Korkut, 
who is regarded as a poet and a scholar, and is finished with his prayers. The Turkish literary historian Fuad Köprülü says that the Dede Korkut epic would still be dominating even if we put all the Turkish literature on one pan of a balance scale and Dede Korkut on the other pan of the scale (Ergin, 2000, p.5).

In Greek mythology there is a mythological story which is common in many ways with the story of "Duha Kocaoğlu Deli Dumrul"; Alcestis tragedy of Euripides, the tragedy author of the V century, B.C. The most important thing in common between Alcestis and Deli Dumrul's story is the motive "to give life instead of his life". There is also a crime committed against the gods In the beginning of this story in the Greek mythology. In both narratives, the starting point is "the motive of sacrifice" (Sina, 2011, p.231).

The story "Dumrul and Azrail" from the book "Forty Rooms with Seven Doors" of the contemporary Turkish Literature writer, Murathan Mungan, is a postmodernist story, whose characters and the structure was created by establishing intertext relations with Duha Kocaoğlu Deli Dumrul story of the Dede Korkut Epic. In this story, Mungan reinterpreted the basic narrative of the epic from the 20th-century point of view. The author, who draws attention to the changes in the concepts of parenting, love and sacrifice, defines Dumrul, as a person who has not yet found himself, whose every corner of the heart and mind has not grown up in the same way and whose eyes are only opened by death (Mungan, 2000, p.122). Unlike the Alcestis and Deli Dumrul stories, no woman in his story will sacrifice her life. This story of Murathan Mungan provided us with a viewpoint to interpret the problems of the epic and present-day society.

The flow of events in the fifth story of Dede Korkut Epic, "Duha Kocaoğlu Deli Dumrul" is as follows: Deli Dumrul (the protagonist of the story) builds a bridge over a dry brook bed and gets 33 coins from anyone who passes the bridge but gets 40 coins, from who does not pass the bridge, by beating them up. One day, he receives news about a young valiant dying. Dumrul wants to learn the cause of the death of the valiant and learns that Azrail (death angel) took his life. Dumrul challenges Azrail. This situation does not appeal to God and sends the Azrail to take his life. While Dumrul is eating, drinking, and sitting with his forty-bold friend, Azrail comes and tells him that he will take his life. When Dumrul finds out the seriousness of the situation, he begs God with pleasing words and apologizes. God declares that he will forgive him, provided that he finds life instead of his life. Dumrul goes to his father first. His father tells Dumrul that he will be able to give his property, his animals, but not his life. His father devoted his life to the material wealth he had. He sends his son to his mother to ask for it. His mother also tells Dumrul what good she has done to him until that day, even the milk she nursed, and does not give her life to his son. Finally, Dumrul goes to his wife to be redeemed, and counts her inheritance as a wife. He tells his wife to marry after death in order not to leave their children as orphans. His wife cries out that she can give him her life. Then Dumrul prayed for God either to take the two of them together, or to leave them to live together. Then God commands the Azrael to take the life of Dumrul's parents. God forgives Dumrul and his wife, and lives them for 140 years.

\subsection{1 th Century and Suphi Alttndöken}

In February 2015, in Turkey's Mersin province, Ozgecan Aslan a young female university student, was brutally murdered by the driver in the passenger van that she was riding to go home. This event was discussed socially in Turkey for a very long time and remained on the agenda. There were protests all over Turkey.

The killer was Suphi Altindoken, 27 years old. Father of Suphi Altındöken was a goldsmith and they were very well off during his childhood. The occupation of goldsmith was inherited from their grandfathers and that was why they have the surname Altındöken (means "gold caster). Suphi, a child initially cherished and loved, he began to become a child who was beaten and pushed by the deterioration of his father's business and of his psychology. Communication problems between his parents also increased. He could not finish elementary school, he started using drugs. He was growing up in a world where the violence, the lack of love, and the lack of communication prevailed. He then married at the age of 20. He always had problems communicating with his wife. They had a son. His father had closed his shop when his business went bad and Suphi Altındöken was working as a driver of a passenger van (Butakin and Akgüngör, 2015).

In her first interview, Suphi Altindöken's mother said: "No child is born as a murderer, thief or a terrorist. Everyone is born as an angel. There are a lot of factors turning him to this. "(Özgecan's Murder Suspect's Mother, 2015).

When a journalist asked her," Do you question yourself when you hear your son's murder? Have you thought that you couldn't raise him well? " she answered as follows: "I made mistakes. Maybe it won't turn this if I had not fought next to my kids. You give a lifetime, you have a huge nothing left in your hands. When I was violated, he watched trembling. Everything was right in front of him. " (Par, 2016).

In the murder of Özgecan Aslan, Suphi Altındöken and his father who helped him after the murder was sentenced to life imprisonment. Then the killer was killed by another prisoner in prison. Suphi Altındöken's funeral was not allowed to be buried because of social pressure despite the five days spent. He had been turned down from all graveyards and from 
funeral services. Nobody wanted to take part in the funeral. His mother, who could not be able to bury her son, said: "By fighting a finished life, not letting his body to be buried, they actually tortured me not him" (Par, 2016).

The inability to perform burial of the Suphi Altındöken's funeral is similar to Antigone, the one-act tragedy of the ancient Greek author Sophocles who lived around 400 BC. Polyneikes, the son of Oedipus, exiles his father to foreign lands, collaborated with foreigners and acts against the state. Two brothers, Eteocles and Polyneikes kill each other, in a power struggle. His uncle Kreon who becomes the King, prevents Polyneikes from being buried because he betrayed the state. It was believed that if a dead in ancient Greece was not buried with ceremonies prescribed by the traditions, he would not be able to pass through the gate of Hades and the spirit would not find peace (Sophocles, 2016, p.55). Antigone, in view of "Every mortal deserves to be buried," secretly buries his brother Polyneikes and pays it with her life. Then, due to the fact that this funeral is not done, the city struggles with many troubles.

Mehmet Aslan, the father of the deceased Özgecan Aslan, over the news that his daughter's killer Suphi Altındöken's body was not buried: "Either on a top of a mountain, or on a plain, but he has to be buried." (Özgecan's Father, 2016) is like a contemporary Antigone call. Then the killer's funeral was buried. These words of Mehmet Aslan are important from the standpoint that the social spirit is rescued from corruption and the goodness continues even if it is contrary to the society as a whole.

\section{Deli Dumrul and Suphi Altındöken}

Deli Dumrul has also grown up in a family similar to Suphi Altındöken where material values are elevated. His father and his mother think that they will be able to avoid of giving their lives to their sons who want their lives with sacrificing their financial means instead. In other stories of Dede Korkut Epic, it is seen that family ties and intra-family relations are very strong. In this story, it is obvious that It has been tried to draw attention by using the weaknesses of family ties, to concepts such as raising children, love and sacrifice.

In mythological systems, there are special types and individuals that we can also define as "oppressed". In myths, punishments are given to constitute a sign, to influence the member of the society and to discipline the one in the framework of the rules set by myth, mythic world view (Abdulla, 2012, p. 296). There is the influence of punishments in Dede Korkut Epic, as well as Alcestis of Euripides and Antigone of Sophocles, regarding the determination and implementation of the social rules.

For Deli Dumrul, apart from being drunk, to challenge Azrail, rob people and use violence against people on the bridge; and for Suphi Altındöken, to kill a person, are not only individual crimes, but also social, as well. Only Godly tolerance can save a person who is arrogant and injustice (Binyazar, 2010, p.84).

In the story of Duha Kocaoglu Deli Dumrul, Dumrul was rewarded with life for 140 years aside from his death sentence. Özgecan Aslan's killer Suphi Altindoken, on the other hand, was sentenced to life imprisonment and then killed by another inmate in prison. What protects Dumrul from death is his wife's love and attachment for him. Dumrul somehow managed to make love exist in his life. Suphi Altındöken's wife, however, opened a divorce before the murder but withdrew the case because of the violence and repression she saw. After the murder, he was divorced from his wife.

Table.1. Deli Dumrul and Suphi Altındöken

\begin{tabular}{lcl}
\hline $\begin{array}{l}\text { Features of Deli Dumrul and Suphi } \\
\text { Alttndöken }\end{array}$ & $\begin{array}{l}\text { Deli Dumrul } \\
(12 \text { th } \\
\text { century) }\end{array}$ & $\begin{array}{l}\text { Suphi } \\
\text { Altundöken } \\
(21 s t \text { century) }\end{array}$ \\
Arrogant & $\checkmark$ & $\checkmark$ \\
Rogue & $\checkmark$ & $\checkmark$ \\
Hot tempered & $\checkmark$ & $\checkmark$ \\
Fond of materials & $\checkmark$ & $\checkmark$ \\
His father is fond of materials & $\checkmark$ & $\checkmark$ \\
Mother-father is out of contact & $\checkmark$ & $\checkmark$ \\
thinks he'll get what he wants & $\checkmark$ & $\checkmark$ \\
Committing a social crimes & $\checkmark$ & $\checkmark$ \\
Growing up without real love & $\checkmark$ & $\checkmark$ \\
Growing up without spiritual values & $\checkmark$ & $\checkmark$ \\
There's only one sister. & $\checkmark$ & $\checkmark$ \\
Substance use such as alcohol-drugs & $\checkmark$ & $\checkmark$ \\
Married, son & $\checkmark$ & $\checkmark$ \\
Loved by his wife & $\checkmark$ & $x$ \\
\hline
\end{tabular}




\section{Parent Attitude}

The characters of the story are Dumrul, God, Azrail, Dumrul's mother, father and wife. We see that the nickname "crazy" of the protagonist of the Story Dumrul is about the characteristics of being stout-hearted, assertiveness and hot temper (Korkmaz, 2006, p.251). The fact that the protagonists of Dede Korkut Epic is made up of the elders of Oğuz, reveals that Dumrul and his family are also the descendants of this clan. It is seen that Dumrul and his family have very good economic conditions and that their parents have plenty of gold, silver money, livestock (sheep, camels, horses), hunting and viticulture is practiced in the region. The presence of summer ranges in the high mountains, cold springs, large fields, flocks, slaughtering nine male camels for the birth of a son, tradition of throwing feasts, golden goblet used by Dumrul and the yurt window being gold are the criteria that show the economic status of the family. However, Dumrul seems to owe property to his father. Because there is no information about the work Dumrul did in the epic, and at the beginning of the epic, we see that Dumrul built a bridge over a dry brook and got thirty three coins from who passes the bridge and forty coins from who doesn't. Why does Dumrul do this? Dede Korkut asks this question and answers: "Why would he do that? For him, though if there is a crazier and a stronger man, saying, 'Come on, fight me, fight and my manliness, my valiance, my gallant, my heroism, my valor will be heard in Damascus and in Rome and acquire fame', he said" (Ergin, 2000, p.113). It seems that Dumrul is not after a livelihood, but in glory and fame. He also has an arrogant attitude. But the sad thing is that he wants to be seen valiant by practicing banditry. Manliness, valiance, heroism and gallant are titles that he already thinks he deserves and can obtain easily. He thinks he can get whatever he wants. The failure to recognize Azrail shows that Dumrul does not have the most basic knowledge of Islam, even though he is a Muslim.

When Azrail comes to take his life, he is drinking wine with forty fellows and having fun. He is also threatening Azrael to frighten him. In the Oguz culture, where respect for elders is extremely high, the words he says should be regarded as disrespectful. Once he has known Azrael and learned that he was sent by God, we see that he beg for forgiveness and try to hide behind excuses. He told him that he was drunk, and that he did not recognize Azrail because he was drinking wine from grapes obtained from the vineyards in this region. He does not know that drinking wine is forbidden according to his beliefs and he forces the people living in the region to his crime. Dumrul asks for God's forgiveness in the presence of Azrael, and God says that he can continue to live if he finds "a life instead of his life". Dumrul goes to his father first to ask for life. He appeals to his father with such qualities as "wise, saint and honored" and tries to win his favor. Until then, it appears that Dumrul's behavior has been reinforced. He is always like a little boy pampered by his father even at the time he was asking for his father's life. This leads to questions such as why he went to his father, In order to ask for a life, why his mother and father were not side-by-side. In the world of Dede Korkut Destan there is a close connection between mother and son. Mothers always retain the property of being the first refugee in the Epic (Savkan, 2004, p.94). They take care of all the danger for their sons and even protect their sons from their fathers when necessary. In the whole of the epic, the father and son are like rivals and almost enemies. They are two important elements of the struggle for power. Could it be the reason that Dumrul wanted to get rid of his biggest rival when he had gone to his father first to ask for life? Dumrul's father seems to have created himself with the wealth of goods unlike the heroism, valor, glory and honor of the Oguz epic world. His father had counted all his own possessions in front of him-seemed like he demanded respect for the fact that he had so many assets while enumerating his wealth-then he said he could not give his life and he directed Dumrul to his mother for asking for life. Is it because his father is aware of this strong relationship between mother and son that he: "Your mother is, more sacred, more beloved than me, reach your mother Son!" cried? Would a man who really loves his wife want to confront her with Azrail? questions pops in one's mind.

When Dumrul goes to his mother after his father, he complains to his mother about his father with his words, "I wanted life from Father Mom, he didn't give. "and hopes that he will be accepted in this way. Dumrul also wants life from his mother, almost self-pitying. In all other stories of Dede Korkut Epic, we came across with strong and protective female figures, who are warriors as good as men. However, only with the "mother" character of Duha Kocaoglu Deli Dumrul story, the opposite was the case. Moreover, she boasts to her son only for carrying out the duties that mothers normally do - to carry them in their wombs for nine months, bring them to the face in the tenth month, stuff them in the cradles, breastfeed them. However, Dumrul's mother preferred to stay in the world instead of saving her son, unlike the other mothers of Dede Korkut Epic. In this story, the mother avoiding the death to save her son, do not comply with the nomadic idea (Kaplan, 1985, p.108).

In this story of the epic, there is no loving home where Dumrul would find his mother and father together to go for asking for life. He visits the two separately to ask for it. The parents could not make a good example for their son, Dumrul. In the end, their lives have ended because of their child that they cannot take responsibility for. Azrail, knocking on the old couple's door is the last piece of the chain of events that Dumrul started (Saydam, 2011, p.172). However, Dumrul held on to life thanks to his wife's love and loyalty. This story differs from other stories in the Dede 
Korkut Epic in terms of enhancing self-sacrifice, loyalty, friendship between spouses (Binyazar, 2010, p.84).

Dumrul goes to the mother of his two sons, his wife to say farewell. He introduced her to Azrail as "daughter of a stranger, my lawful wife" When he faces his spouse he tells what happened and starts counting the property he owes, the high black mountains, the horses, his home, his sheep one by one, just like his father. Moreover, he tells her that she is free to marry anyone she trusts just keep his tow sons from being orphans. Dumrul's wife - who was not named in the story - was the person who gave the greatest reaction to those who had told him that she would give his life to Dumrul. His wife's words are full of love, affection and sacrifice. This woman, with her wise and noble attitude, shows Dumrul both the right and the wrong, the values like loyalty, commitment, and the what feeling of love is like.

Dumrul seems to have noticed his mistakes while begging God again. This time he makes promises to God that he will do what he has to do before. He will build charity homes, help the hungry and the poor. As long as God takes their lives both or leave them together to live. The promise of Deli Dumrul pleases the god and he forgives both of their lives and granted them with a life as long as 140 years. He takes lives of Deli Dumrul's both parents.

In the Dede Korkut Epic, which is a product of a nomadic society, raising children is provided by traditions and customs. The child who does not listen to the words of the elders will be taken with a dim view (Arı and Karateke, 2010, p.282). Adopting as a role model is a case that cared significantly. Dede Korkut "The girl does not take advice if she does not see it from the mother, and the son does not set a table if he doesn't see it from his father." (Ergin, 2000, p.16). Boys are even getting their names, with their success. An understanding that forces children to be valiant and strong at an early age dominates.

In the story of Deli Dumrul, a situation opposite to the child education of Oghuz Tribe is observed. All the material needs of Deli Dumrul seem to have been fully covered by the family since the day he was born - without expecting any success or hard work. Dumrul is a son that seven male camels slaughtered in his honor. Dumrul is trying to achieve glory and fame even in a situation where he is unjust. He expects that the unlimited opportunities offered to him by his parents will be given by everyone, and he expects even Azrail to almost obey him because of his power and reputation. Out of Dumrul's family life, rules and order replaced compassion and care, tolerance and pampering replaced by the order of obedience (Saydam, 2011, p.246). Dumrul is living a great confusion. The weakness of the communication between the father of Deli Dumrul and his mother, the situations where they gave up each other and their sons, the indulgences of the world's goods and their lives have cost their own lives. Moreover, they raised a son who tortures people on the bridge that he established, uses violence, thinks that he can be superior to others via the means of wealth, do not fulfill the requirements of his beliefs (recognizing angels, drinking wine), unable to give love and compassion and provide moral values to his children. However, in other stories of Dede Korkut Epic, we see that there is an infinite love and compassion in relations, a connection that is not loosened in the face of deaths, but a getting firmer, a loyalty tested by the heaviest and most powerful experiences (Gökyay, 2003, p.17). Dede Korkut, the bard who is the narrator of the epic says "The mighty God would never make you lean on the despicable!" in his pray at the end of the epic and Deli Dumrul's wife says "Your despicable mother and father, what is in a life that they couldn't sacrifice it in your name?" in the epic. The community addresses the parents who do not take care of their offspring as "despicable".

\section{Result and Discussion}

Seeing that mythological stories and heroes carry almost the same characteristics as the real stories and heroes of today's world means that they can turn to mythology for the solution of any problem that today's people are forced to solve. Suphi Altindoken also grows up - similar to Dumrul -in a family where he is pampered for just being a man, but unlike Dumrul, there is also physical violence. Both Dumrul's and Suphi Altındöken's families are dominated by lovelessness and lack of communication. Deli Dumrul abuses alcohol and Suphi Altındöken abuses drugs. They both commit divine offenses by tormenting people. However, Dumrul's superiority over Suphi Altındöken is being loved by his wife with a great passion. Mythology is a mirror from the past that shows as the possible reasons and likely results of events. If we look at the murder of Ozgecan Arslan in modern Turkey, from the Dede Korkut Epic Story Duha Kocaoglu Deli Dumrul, causes and consequences of events can be summarized as follows:

1. Being a parent requires great responsibilities and sacrifices. In myths, mothers and fathers who can not teach good and right to their children and can not be good examples for their children are punished. Mom and dad should be able to give their lives for the sake of their child, if necessary. Otherwise, they deserve the greatest punishment.

2. Love and affection solve all matters. Real immortality is also in love. What makes two people family; Is love.

3. Who can have someone that can give a life instead of her/his own life, $\mathrm{s} / \mathrm{he}$ is a winner of a great prize or someone who has tasted the immortality. 


\section{References}

Abdulla, K. (2012). Gizli Dede Korkut. Ankara: Ötüken Yayınları, 2012

Arı, B., \& Karateke, E. (2010). Dede Korkut Hikâyelerinde Kadın ve Çocuk Eğitimi. Mustafa Kemal Üniversitesi Sosyal Bilimler Enstitüsü Dergisi. 14, 275-284

Armstrong, K. (2014). Mitlerin Kısa Tarihi. İstanbul: Alfa Yayınları

Bayat, F. (2007). Mitolojiye Giriş. Ankara: Ötüken Yayınları

Binyazar, A. (2010). Dede Korkut. İstanbul: Yapı Kredi Yayınları

Butakın, K. \& Akgüngör, İ. (2015, June 18). An Villain's Anatomy. Vatan News Center. Access Address: www.gazetevatan.com/bir-caninin-anatomisi--741166-gundem/

Campbell, J. \& Moyers, B. (2013). Mitolojinin Gücü. İstanbul: MediaCat Kitapları

Çobanoğlu, Ö. (2003). Epik Destan Geleneği. Ankara: Akçağ Yayınları

Dumézil, G. (2012). Mit ve Destan I. İstanbul: Yapı Kredi Yayınları

Ergin, M. (2000). Dede Korkut Kitabı. İstanbul: Boğaziçi Yayınları

Euripides. (1964). Alkestis. (trans. A.H.Tanpınar) İstanbul: Milli Eğitim Basımevi

Fiske, J. (2014). Mitler ve Mitleri Yapanlar. İzmir: İlya İzmir Yayınevi

Gökyay, O. Ş. (2003). Dede Korkut Hikâyeleri. İstanbul: Dergâh Yayınları

Homeros (2004). İlyada. İstanbul: Can Yayınları

http://www.hurriyet.com.tr/ozgecanin-katil-zanlisinin-annesi-o-annenin-babanin-ayaklarini-operim-28220086 （2015, February 17)

Kaplan, M. (1985). Dede Korkut Kitabinda Kadın. Tiirkiyat Mejmuasi

Korkmaz, Z. (2006). Dede Korkut Hikâyelerinde İnsan ve Doğa. Türk Dili. 657, 250-257.

Mother of Özgecan's Murder Suspect: “I kiss her mother's, father's foot.”. Hürriyet Gazetesi. Access Address:

Mungan, M. (July August 29, 2000). Dumrul ile Azrail. Adam Öykü. 117-140

Özgecan's Father Speaks on Live Broadcast. Milliyet Gazetesi. Access Address: http://www.milliyet.com.tr/ozgecan-in-babasi-canli-yayinda-gundem-2225956/, (2016, April 12).

Par, K. Mother of Özgecan's Murder: "When my husband beat me, my son trembled and watched over us.". Habertürk Gazetesi. Access Address: http://htdokun.haberturk.com/ana-gazete/haber/1229437-ozgecanin-katilinin-annesi-ben-siddet-gorurken-o-titreyer ek-seyrederdi ( 2016, April 23).

Savkan, H. (2004). Dede Korkut Kitabı'nda Anne-Çocuk İlişkisi. Balıkesir Üniversitesi Sosyal Bilimler Enstitüsü Dergisi, 12, 90-103.

Saydam, M. B. (2011). Deli Dumrul'un Bilinci. İstanbul: Metis Yayıncılık

Segal, R. A. (2004) Mit. Ankara: Dost Yayınları

Sina, A. (2011) Alkestis ve Deli Dumrul. AÜ Türkiyat Araştırmaları Enstitüsü Dergisi (TAED), 46, 157-180.

Sophokles (2016). Antigone. İstanbul: İş Bankası Kültür Yayınları

\section{Copyrights}

Copyright for this article is retained by the author(s), with first publication rights granted to the journal.

This is an open-access article distributed under the terms and conditions of the Creative Commons Attribution license which permits unrestricted use, distribution, and reproduction in any medium, provided the original work is properly cited. 